\title{
On studying religion, the media and young people
}

\section{Introduction}

This article charts a unique and important phase of media use and meaningmaking processes among young people during the first decade of twenty-first century. The rapid changes in media content and consumption have brought about a transformation which impacts on forms of religion and spirituality for young people. In this article I review four studies on the field of religion and the media. Key concepts of the construction of individuality and the narrative of personal biographies are found in all of them. The role of Evangelical Christianity and the core narrative of the apocalypse, as well as the clear polarities of good and evil are analysed in two of the studies which give a description of the global and transnational dimension, while the other two put more emphasis on the local, cultural and historical dimensions.

The significance of the transnational character of religious narratives, the media and popular culture is analysed in reference to a long period of ethnographical inquiry and detailed documentations of the cultural discourses associated with musical subcultures as well as the locality and new media conventions approach in the studies of existential and religious expressions in the mediated environment.

Lynn Schofield Clark (2003) interviewed teenagers and their families in the United States in the period 1996-2002, enquiring into their relationship to entertainment, the media and supernatural themes in these. Mia Lövheim's study (2004) of participators in an internet discussion group describes the unexplored use of new media in the making of religious identity and the processing of it in textual expression in Sweden. Tomas Axelsson's (2008) focus went deeply into the relationships between mainstream popular film culture and the meanings given in individual worldviews. Marcus Moberg's (2009) study of Christian heavy metal musicians describes the dialogue between popular culture and the creation of a special musical space or scene in the religious and artistic expressions of Christian faith and popular, material culture within the media, lifestyle and aesthetic dimensions. 
The significance of these studies is the contemporary phenomenon of a recent development of media and popular culture which are central agents in the lives of young people in terms of gaining an understanding of the forms and expressions of spirituality and everyday religion. First, they all are studying the relation of young people and the dimension of material culture in contemporary Western society from a broad perspective. Second, they bring in the use of the media, entertainment and popular culture as a seminal part of the grand processes of religious change in late modern society. Questions of the secular, the post-secular and the rise of spiritualities, religious affiliations, the media and institutional religions and their relationships are central to an understanding of the complex world we live, consume and communicate in, in relation to religion and spirituality (see e.g. Morgan 2008; Hjarvard 2008; Lundby 2009; Clark 2003, 2007; Day 2011, 2012; Lövheim 2004, 2007; Lynch 2005, 2007, 2012; Moberg 2009; Moberg and Granholm 2012; Nynäs et al. 2012; Woodhead and Heelas 1998). The question of authenticity and authority over the use of religious symbols and expressions are contested by a set of authorities - religious and media-based (Hoover 2008: 33-4).

Institutional religions are changing ideas with popular culture products which are visible and recognised and thus accessible in terms of emotional identification. In return, popular culture is manufacturing, consuming and melting the beliefs, ideas and narratives of religion and spirituality (see e.g. Frönäs 1995, Lundby 2009, Hoover 2008). The new forms of media and religion are studied inside the triangle constituted by the criteria of youth, popular culture product and ideological or religious institution. The meaningmaking process and identity formations that are studied occur in and with the media. Together, popular culture and new media expressions are creating new ground upon which teenagers are expressing or 'doing' religion and as such, constructing and expressing ideological and religious identities.

The approach in these studies is built on the concept of a constructionist view of religious identity in the mediated landscape (see e.g. Clark 2003, Lövheim 2004, Axelson 2008, Moberg 2009). From a sociological angle, cultural learning or socialization involves two phases, where the first is led by the family and tradition. In the second phase other agents which have authority in the life of individual - such as school, the media and peer groups - emerge. According to Anthony Giddens (2006: 163-7, 534) the agencies of socialization push the individuation process towards self-awareness. A sense of purpose is one of the three main features in the process of religious socialisation and is the central opposite form in the discussion of the secularization and the role of the media in it (see e.g. Taira 2008, Jenkins 2006). The rise of spiritual- 
ity (see e.g. Woodhead and Heelas 1998) and Evangelical Christianity (see e.g. Clark 2003, Moberg 2009) in particular exemplify the interaction of religious institutions and the mass media. The creation of media content for religious and ideological purposes has both positive and negative consequences. The studies approach the discussion of the relation of strategic choices of an individual and larger social change in institutional religions and spirituality. In late modern society religious narratives are circulated along with popular culture products. The dynamics of good and evil and the pursuit of happiness collide and interact in these products and the authority of the use of symbolic content is claimed in several ways in the entertainment media, internet or scene.

\section{Young people, religion and the media, locally and globally}

The prevalence of the media in everyday life has changed the way children and adolescents spend their leisure time. The consumption and permeable dimension of the media (see e.g. Lundby 2009, Lynch et al. 2012) is at the centre of our everyday lives: at home, school and work. During the last decade the media environment has been developing swiftly. The typically shared, familyowned media appliances - such as the television, telephone and computer, have been replaced with a multitude of private, personally-owned media devices. This progression has been exceptionally rapid during last ten years and today the mobile phone is a central tool for communication, entertainment and social media representations among teenagers. This development has also privatized the circumstances in which children and young people spend their time.

The transformation and usage of the symbols of the religiously dominant narratives (see e.g. Hjarvard 2008, Clark 2007, Day 2012, Hoover 2008) and of the impact of audience response is an area of interest for the institutions which play key roles in in children's and young people's lives. Moral and ethical narratives are in generally situated in the institutional religion. These core narrative structures (Hjarvard 2008: 158-68) are shaped by and in the media and they are shared both globally and locally. The interaction between individuals and social representations and institutions are discussed, negotiated and represented in popular cultural products including music, television shows, films, games, magazines and the content of digital environments for communication and entertainment. The production and distribution of entertainment and popular culture is transnational and interpretations are 
dependent on the terms of interaction between individuals and institutions, cultural, historical, ideological and religious; the emphasis on narration and the audience in specific context and resources and the complexity of these is visible in the studies.

\section{Four approaches, three countries and Christianity: the United States, Sweden and Finland}

\section{United States}

Media reception studies commonly rely upon the assumption of a direct impact of the media text in question. The media text is analysed, transmitted to the audience and afterwards the audience write their responses. Anthropological approaches have led media researchers also to draw attention to the context that shapes the interpretations of the media. Focusing on religion in the media, Lynn Schofield Clark (2003) has employed ethnographical methods to investigate the role of the supernatural in the United States. A three-stage ethnographical study began with the formation of a research project in 1996 which was finished in 2002. Clark specialised in adolescent and feminist qualitative methods in research design in her study of teens in relation to their families and their media consumption. The teenagers numbered 102 and Clark continued the ethnographical study with five teens and their families which formed the core of her study.

In From Angels to Aliens: Teenagers, the Media and the Supernatural (2003) Clark introduces us to the mediated environment as it was at the turn of millennium in the United States. Theories of rational, individual action of choice are challenged by the significance of the circulating public religious symbols of the nation interacting with individual ones and transforming religious narration (Clark 2003: 12-15).

The impact of Protestant Evangelicalism on the mediated landscape is pivotal in the study. Clark discusses the aspect of Evangelicalism in which good and evil dichotomies are present and the narratives of the Apocalypse and the End of Times are one of the most popular, along with the idea of the supernatural. At the same time the potential for Evangelical conversion, religious authority and definitions of morality transforms the discussion of the media towards Christian entertainment and non-Christian entertainment (Clark 2003: 24-37). The relationship between Protestant Evangelicalism and the media brings out questions of the dynamic of being on the side of the right, where the moral winners leave the others behind. 
Clark (2007: 78-82) also underlines previous findings that young people are articulating views on moral sustainability and ethical beliefs which are derived from the themes of Protestant Christianity are coming from teenagers who do not claim to belong to any institutional religion. The close relation of religion and morality in United States and the issue of how they are represented in the media also makes it difficult to separate what belongs to institutional religion and to the sphere of spirituality (Clark 2003: 228-36).

The young people who do not identify themselves with institutional religions or traditions, however, do, through products from popular culture, identify and express the same moral narrative structure of good and evil that is characteristic of Protestant Christianity. Entertainment media audiences do not all open their minds to possibilities and the content of entertainment is chosen from the tradition. Most of the teens interviewed understood an openness to possibilities as one of the ideal and mediated belief systems in a multicultural environment.

Freedom of choice and opening up to possibilities in real life are limited by cultural, racial, educational and socio-economic factors. In the US context the beliefs of the teenagers echo the individualism that is represented in the entertainment media and which reproduces the hegemonic profile of the nation. Thus, Clark suggests that an analysis of media consumption should be integrated with ideological and political questions (Clark 2003: 228-36). According to Clark the enjoyable and entertaining question of 'what if' and identification with media constructions of belief should be analysed in terms of the negative and narrowing dimension they are promoting.

\section{Sweden}

Mia Lövheim focuses on the constructive process of religious autobiographies in her study Intersecting Identities: Young People, Religion, and Interaction on the Internet (2004). The dynamics of the dominant institutional impact of the media and the concept of constructing identity in late modern society are central. In order to find out about the process of constructing religious identities Lövheim analyses interactions which took place in the religious discussion groups of a Swedish website and shows how interpretations of authenticity are dominant. Analysing the discursive patterns under the topics of religious tradition or ideology, Lövheim finds patterns of asserting authorities and personal experience in the expression of authentic argument (Lövheim 2004: 42, 122-3).

The arguments are valued by the peers in the website groups discussing religious matters in Protestant Christianity, science and reason and the su- 
pernatural as well as new religious movements. The core of insiders and more disparate outsiders is established by the test of religious symbolism and how it is used in their written arguments. Lövheim shows in her analysis how the insider group approves or rejects interpretations, based mainly on the use of the symbolic content of religion (Lövheim 2004: 256).

Discourse analysis, along with semi-structured interviews serves to indicate how symbols and ethical dichotomies, along with an authentification of the sources, become central for the participants in internet discussion groups. In the discussion groups the coherent and credible use of religious symbols, as well as the support of personal website representation are all ways of establishing authority. The use of these discursive tools for forging religious autobiographies underlines some of the features that communicate trustworthiness and authenticity. In order to achieve or maintain a position of influence in the discussion group, competence in text-based discussion is required and this introduces new forms of authority (Lövheim 2004: 252-7 and 2007: 93-5).

The negative side of the group dynamic also emerged. The informant and researcher reconstructed the meaning of text-based discussion conventions and negative experiences within the discussion groups. Interactions on the internet do not seem to differ greatly from daily conventions, though they may sometimes increase the risk of misunderstanding expressed intentions. The study reports on the complexity of individual resources and conditions on the chosen website. The institutional and religious narratives and symbols of a particular society structure the understanding of religion and the dynamics of the construction of religious traditions in the media (Lövheim 2007: 93-7).

In his study, entitled Film och mening. En receptionstudie om spelfilm, filmpublik och existentiella frågor (2008; Movies and Meaning: Studying Audience, Fiction Film and Existential Matters) Tomas Axelson considers the interactions of film audiences, the making of meaning and the construction of belief. By developing reception and audience studies he is able to develop an understanding of belief systems and the existential questions prompted by popular fiction films. The relationship between the media and interpretations of the products of popular culture throws light on the social interactions between audiences and films and how films relate to the construction of meaning.

Axelson employs methods from media and film studies, psychology, social psychology, sociology and theology. The audience studies approach was motivated by the design of a research project on a film audience made up of 197 Swedish university students and the approach was refined with the addition of in-depth interviews. Axelson (2008: 235-47) charts the references between filmic narration and lives of his interviewees. 
This method combines quantitative and qualitative approaches. The key concept of the interpretative horizon refers to the process of socialization and it is defined collectively and ideologically by means of a set of values. In the study Axelson (2008) employed a questionnaire for the 197 students and continued with focus group discussions, identifying three different interpretative horizons of, respectively, more, less and mixed religious socializations. The question of socialization and religious change form the framework upon which Axelson (2008: 238) rests the hypothesis of three features. The hypothesis proposes that the group of individuals with religious socialization rest their interpretations on the existential questions of religious origin and the existential interpretation of film is employed with less, or mixed, religious socialization and thus observed in the interpretation horizon. This hypothesis suggests that secular individuals replace the values and beliefs with the narratives and material products of popular culture. The semi-structured interviews and screening of personally-chosen films refines the audience study. The analytical tool examined the films' reception, as well as existential interpretations and the implementation of the interpretation in narrative schema.

The discussion of the results suggests that the comprehension is creative and unique when it is attached to the existential interpretations and expressed in relation with inherent interpretative horizon (Axelson 2008: 246-7). The film and entertainment media are used as a cultural resource and a reflection of individual belief systems. The cultural environments are different and institutional agencies have an impact on the interpretations that allow dissimilar conclusions to be reached in US and in Sweden. The findings can be aligned with those of Lynn Schofield Clark (2003). The concept of creative interpretation indicates the seminal question of free choice and the opportunities inherent in a particular historical and cultural environment.

\section{Finland}

It is becoming increasingly difficult to ignore the rapid changes occurring in the media, or the importance of popular culture in shaping alternative religious and spiritual identities and forms of new religious expression. Marcus Moberg's seminal study of Christian metal music outlines a whole subculture that is based on the intention to convey a Christian, evangelical message. The music scene is doing religion and being Christian in a particular way that comprises lifestyle, aesthetics, the festival scene and material cultural dimensions which Moberg (2009: 1-9) outlines as occupying three central dimensions. The first of these dimensions of Christian metal media includes magazines - amateur magazines, that is fanzines - internet sites, discussion forums, 
and the official webpages of Christian metal bands. Secondly, the content of the Christian metal music lyrics sets them apart from the secular metal bands and foregrounds an alternative means of expressing one's Christianity. The last dimension is that of consumption and the centrality of the associated lifestyles and visual aesthetics, which are represented in clothing and as part of live concert performances and music videos.

The interviews open up a view of the popular music scene of Christian metal music from an authoritive angle. The interviewees consist of 19 musicians and three producers or administrators of the transnational media in Swedish, Finnish and English. Along with the approach of social and identity constructions, the concept of scene is key to the study. Popular music studies employs this concept, referring to aspects of the production, consumption and experience of popular music in various forms and the specific structure of all of them. The concept of scene connotes the strong spatial and visual features of the performing arts (Moberg 2009: 34-41). The concept of identity is asserted as relational and constructive and it comprises the characteristics which define an individual in relation to others. At the same time it involves both positive and negative expressions of the self in negotiation with others. Moberg (2009: 38-9) discusses issues of freedom of choice and identity. The expressions of identity-narration or personal biographies delineate the past, present and future of an individual and thus are related to temporality and change. Being part of a group, expressions of ethos and the dimension of belonging through material acquisitions and consumption are the forms of identity constructed in the scene of Christian metal as well as in other subcultures.

The discursive analysis of of the vast material culture and the interviews identify the characteristic patterns of the Christian metal scene.

Moberg (2009: 80-4) sets out the development of social change in the 1990s in Finland, when religious uniformity opened out into a more pluralistic environment. The process of weak religious socialization among young people and the central role of popular culture as resource for spiritual and religious insight is also discussed. In this process of social and cultural diversity Moberg (2009: 106-7) shows the relationship between Christian metal scenes and Evangelical apocalyptic themes, as well as the general nature and popularity of metal rock music in general, as the reflection of an increasing uncertainty in post-industrial and secularized societies, where the consequences of change have the greatest impact on working class youth. 


\section{Why should we study young people?}

The four studies presented young people as authors of their own narratives. They were studied as audience members, students, artists and teenagers in order to comprehend the processes of interaction in mediated cultural change. The main focus of the studies in question is the relationships between the media, society, religion and the individual. These relationships are intertwined with fictions, beliefs and narratives and the dimensions of manipulation. Freedom of choice has brought along with it difficulties in grasping the general socio-economical view, as Clark noted. On the one hand, media culture is dominant with the commercial character of the global marketplace with a visibility of ideologies and religions and with the drive to sell. The call for alternative and new forms of expressing spiritual and religious conviction and life styles is found in the subcultures or scenes of fandom and artistic creation, as Moberg stated, but not without the negative aspect of everyday conventions of exclusion and inclusion in the groups, which have lot in common.

The process of belonging in the mediated environment is dependent on the acquisition of skills and knowledge; mastering content and symbolic and economic resources as Mia Lövheim points out. Individuals are reaching maturity in an environment characterised by information overflow and choices that seem infinite are in fact narrow. The resources and building blocks of individuality bring up issues of authenticity and authority. The changing media environment and the required strategies to meet it need to be tested in the media-saturated environment. The understanding of the function and structure of authenticity in the creation of narratives of the self and claims as to the authority of this creation are central in the individuation process. Abby Day (2012: 42-3) refers to several studies of the relations of belief which show that young people value beliefs that are chosen freely and are experienced as and felt to be personal and meaningful. The sense or feeling of belonging is counter to the sense of individualism. In the context of relationships with parents and the family, the formation of belief is authentic and shapes the beliefs of the children. It is at the heart of our understanding that structures of meaning include the emotional dimension (see e.g. Day 2012, Riis and Woodhead 2011).

The centrality of identification, group formation and shared feelings are related to active audience studies and fandom studies. In the consumer society the symbolic system of rarity and exclusiveness has changed and the material dimension of life can be reached by almost everyone (Riis and Woodhead 2011). The basic need to belong, to share values and beliefs constructs an au- 
thentic and constructive element for identity in social interactions. The varieties and changes of the group process of identity therefore need more attention in the study of young people, media and religion. The roles of institutions in socialization and the dynamic relations of family, institutions, peer groups and media need to be approached creatively.

The art of asking the right questions is at the core of the professional skills that a doctoral student performs in the construction process of the identity of the scholar. Building new approaches and circulating old ones in order to study the relationships between popular culture and creative narratives of the individual presumes a tolerance for the prevailing climate of change in the media. Studies of religion and spirituality among young people requires understandings of groups and roles and the organisation of experience in media environment. The contemporary modes of religious socialization, particularly in media, provide new fields of meticulous inquiry in late modern society.

\section{Bibliography}

\section{Axelson, Tomas}

2008 Film och mening. En receptionsstudie om spelfilm, filmpublik och existentiella frågor. Acta Universitatis Upsaliensis. Uppsala: Uppsala University Library. Available online: <http://uu.diva-portal.org/smash/record.jsf?=pid=diva2: $171227>$ (accessed 30.10.2012).

\section{Clark, Schofield Lynn}

2003 From Angels to Aliens: Teenagers, the Media, and the Supernatural. New York: Oxford University Press.

2007 Religion, twice removed: exploring the role of media in religious understandings among secular young people. In Nancy Ammerman (ed.), Everyday Religion: Observing Modern Religious Lives; pp. 69-82. Oxford: Oxford University Press.

\section{Day, Abby}

2011 Believing in Belonging: Belief and Social Identity in the Modern World. Oxford: Oxford Univeristy Press.

2012 Non-religious Christians. In Tore Ahbäck (ed.), Post-Secular Religious Practices; pp. 35-47. Åbo: Donner Institute for Research in Religious and Cultural History.

Frönäs, Johan

1998 (1995) Kulttuuriteoria. Tampere: Vastapaino.

Giddens, Anthony

2006 (1991) Sociology, fifth edition. Cambridge: Polity Press. 


\section{Hjarvard, Stig}

2008 En verden af medier. Medialiseringen af politik, sprog, religion og leg. Fredriksberg: Samfundslitteratur.

\section{Hoover, Stuart M.}

2008 Audiences. In David Morgan (ed.), Key Words in Religion, Media and Culture; pp. 31-42. London: Routledge.

\section{Jenkins, Henry}

2006 Convergence Culture: Where Old and New Media Collide. New York: New York University Press.

\section{Lövheim, Mia}

2004 Intersecting Identieties: Young People, Religion and Interaction on the Internet. Uppsala: University of Uppsala.

2007 Virtually boundless? Youth negotiating tradition in cyberspace. In Nancy Ammerman (ed.), Everyday Religion: Observing Modern Religious Lives; pp. 83-102. Oxford: Oxford University Press.

\section{Lundby, Knut (ed.)}

2009 Mediatization: Concept, Changes, Consequences. New York: Peter Lang.

\section{Lynch, Gordon}

2005 Understanding Theology and Popular Culture. Oxford: Blackwell Publishing.

2007 What is this religion in the study of religion and popular culture. In Gordon Lynch (ed.), Between Sacred and Profane: Researching Religion and Popular Culture; pp. 125-42. New York: I.B. Tauris.

2012 The Sacred in the Modern World. Oxford: Oxford University Press.

Lynch, Gordon, Jolyon Mitchell and Anna Strhan (eds)

2012 Religion, Media and Culture: a Reader. London: Routledge.

\section{Moberg, Marcus}

2009 Faster for the Master! Exploring Issues of Religious Expression and Alternative Christian Identity within the Finnish Christian Metal Music Scene. Åbo: Åbo Akademi University Press. Available online: <https://www.doria.fi/bitstream/ handle $/ 10024 / 59443 /$ MobergMarcus.pdf? sequence $=2>($ accessed 30.10.2012 $)$.

\section{Moberg, Marcus, and Kennet Granholm}

2012 The concept of post-secular and the contemporary nexus of religion, media, popular culture, and consumer culture. In Peter Nynäs, Mika Lassander and Terhi Utriainen (eds), Post-Secular Society; pp. 95-128. New Brunswick, NJ: Transaction Publishers.

Morgan, David (ed.)

2008 Key Words in Religion, Media and Culture. London: Routledge.

Nynäs, Peter, Mika Lassander and Terhi Utriainen (eds)

2012 Post-Secular Society. New Brunswick, NJ: Transaction Publishers.

Pesonen, Heikki, Elina Lehtinen, Nelli Myllärniemi and Minja Blom (eds)

2011 Elokuva uskonnon peilinä. Uskontotieteellisä tarkennuksia länsimaiseen populaarielokuvaan. Uskontotiede-sarja. Helsinki: Helsingin yliopisto. 
On studying religion, the media and young people

Riis, Ole, and Linda Woodhead

2011 Sociology of Religious Emotion. Oxford: Oxford University Press.

Taira, Teemu

2008 Uskonto ja fanius. In Kaarina Nikunen (ed.), Fanikirja. Tutkimuksia nykykulttuurin fani-ilmiöistä; pp. 121-41. Nykykulttuurin tutkimuskeskuksen julkaisuja 96. Jyväskylä: Nykykulttuuri.

Woodhead, Linda, and Paul Heelas

1998 Religion in Modern Times: an Interpretive Anthology. Oxford: Blackwell Publishers. 